\title{
Editorial: A Message from the Chair of the Board of Regents
}

June 17, 2005

Assalamu Alaykum;

On the occasion of 38th Annual convention of Islamic Medical Association of North America (IMANA), we congratulate the Executive Committee for a job well done. Renewing the publication of JIMA is a wise decision that needs support from the Board as well as from the membership. We thank Dr. Hossam Fadel and the editorial board for taking up this challenge. JIMA is the mouthpiece and flagship of IMANA. Through it, not only we bring to its readers the new scientific development but also the Islamic perspective in Medicine and Medical ethics. In this issue, we present to readers the Medical
Ethics position papers developed by the medical ethics committee of IMANA and approved by the Board of Regents on May 14th, 2005. We are looking forward to comments from membership of IMANA and readership of JIMA on these issues. JIMA will have full support from the board. IMANA's mission is to become a leader in health care issues nationally and globally within Islamic guidelines. IMANA and the new executive committee have many challenges ahead but together we will meet them all. In the last 38 years, IMANA has come a long way, but it still has a long way to go. We wish the best for the new executive committee. Wassalam.

Shahid Athar, MD

Chair, Board of Regents, IMANA 